\title{
Stickler syndrome: a possible presentation of Pierre Robin sequence
}

\author{
Filipa Briosa, Sara Oliveira, Rodrigo Sousa, Paulo Oom
}

Department of Paediatrics, Hospital Beatriz Angelo, Loures, Portugal

\section{Correspondence to} Dr Filipa Briosa,

filipabriosaneves@gmail.com

Accepted 17 January 2019

\section{DESCRIPTION}

We report a preterm female neonate with a positive combined first trimester screening (performed at 12 weeks of gestation), diagnosed with micrognathia, mandibular hypoplasia and retrognathia on prenatal ultrasonography. The serological screening was negative with immunity for rubella. Her mother had psoriasis and a sickle cell trait and her older sister had retrognathia and cleft of the soft palate. Due to the patient's prenatal ultrasonographic alterations as well as to her older sister's malformations she was submitted to a prenatal genetic screening. Amniocentesis revealed a normal cariotype with a positive array for Stickler syndrome (SS). She was born by eutocic delivery at 32 weeks of gestation with a birth weight of $1795 \mathrm{~g}$ and needed no resuscitation. On examination she presented with Pierre Robin sequence (PRS) (mandibular hypoplasia, marked retrognathia and cleft of the soft palate) (figures 1-3). She presented respiratory distress with $\mathrm{CO}_{2}$ retention within 24 hours of life, needing mechanical ventilation until the 14th day of life. Enteric nutrition was initiated on the second day of life with a nasogastric tube. Eye red reflex and newborn hearing screening were normal. A complete eye examination was performed and revealed no alterations. She presented with multiple episodes of bradycardia and apnea secondary to glossoptosis which reverted with manipulation. The patient was submitted to a successful early mandibular distraction at 3 months of age and is currently being followed-up by a multidisciplinary team including specialists from plastic surgery, physical

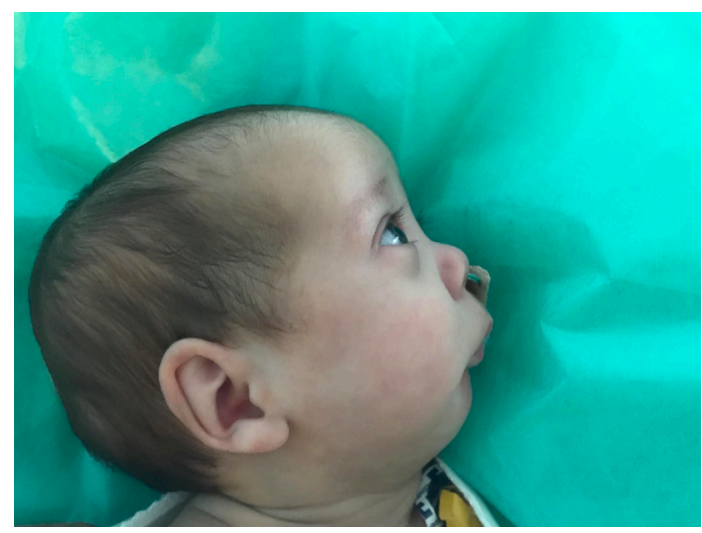

Figure 1 Typical facial abnormalities in Stickler syndrome: a flat midface with a depressed nasal bridge, short nose, anteverted nares and a marked micrognathia (lateral view).

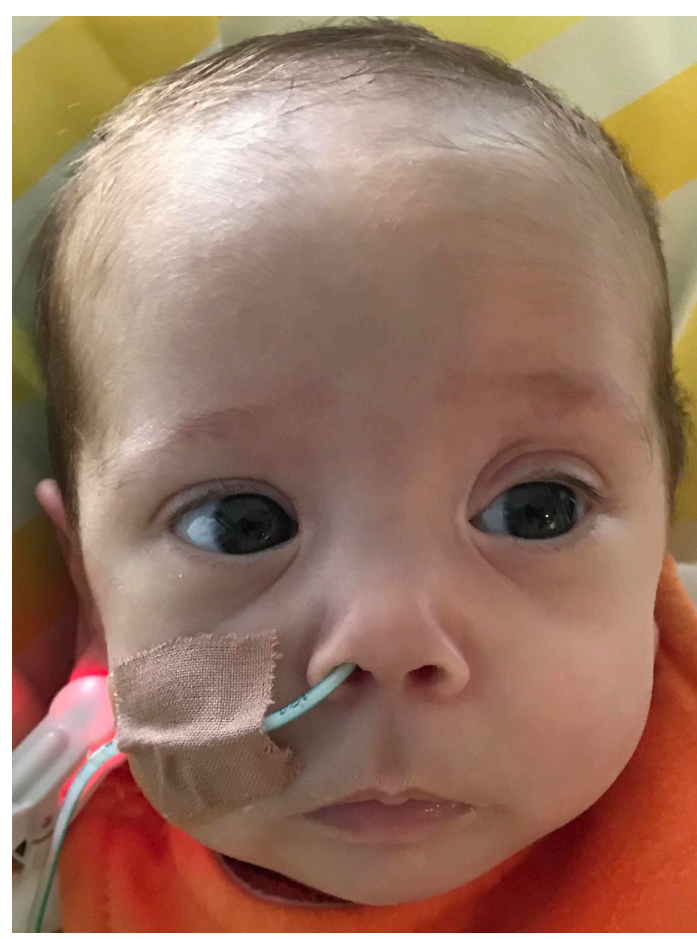

Figure 2 Typical facial abnormalities in Stickler syndrome: a flat midface with a depressed nasal bridge, short nose, anteverted nares and a marked micrognathia (frontal view).

rehabilitation, ophthalmology, otolaryngology and orthopaedics. Furthermore the patient's older sister was also subsequently screened and diagnosed with SS.

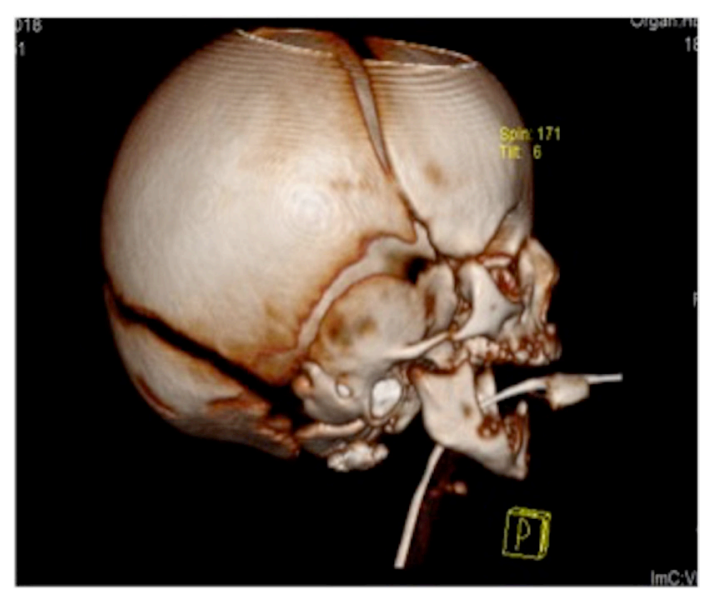

Figure 3 Facial CT in three-dimensional resolution matching clinical orofacial features. 
PRS, characterised by micrognathia, glossoptosis and cleft palate, is associated with upper airway obstruction and feeding difficulties and its treatment consists in a corrective surgical distraction of the mandible. ${ }^{1}$ It is often an isolated abnormality but in some cases occur as part of a syndrome with multiple malformations. One-third of the patients with associated malformations presents SS. ${ }^{1}$ SS or hereditary progressive arthro-ophthalmopathy is a connective tissue disorder affecting about $1 / 7.500$ to $1 / 9.000$ newborns with a predominantly autosomal-dominant inheritance. ${ }^{2}$ It is characterised by orofacial, ocular, skeletal and auditory abnormalities. ${ }^{1-3}$ Affected children typically have a flat midface with a depressed nasal bridge, short nose, anteverted nares and micrognathia. Cleft of the soft palate can occur and is associated with PRS. ${ }^{13}$ Abnormalities of vitrous gel architecture are pathognomonic, usually associated with high myopia and retinal detachment. Joint hypermobility is present in infancy and osteoarthritis typically develops in the third or fourth decade. Sensorineural deafness and mitral valve prolapse may occur. Stature and intellect are usually normal. ${ }^{3}$ Management should include not only a corrective distraction of the mandible for PRS but also an early follow-up in ophtalmology, orthopaedics and otolaryngology consultations since blindness, hearing loss and osteoarthritis may be among the main long-term complications. ${ }^{13}$

\section{Learning points}

- Pierre Robin sequence is usually an isolated entity but in some cases can occur as a part of a syndrome.

- A high index of suspicion is needed to consider the diagnosis of Stickler syndrome in children with Pierre Robin sequence with ocular, skeletal and/or auditory abnormalities.

- Stickler syndrome requires a wider therapeutic approach when compared with isolated Pierre Robin sequence.

Contributors $\mathrm{FB}$ and $\mathrm{SO}$ wrote and designed the primary manuscript. RS and PO were responsible for the critical revision and the approval of the final version.

Funding The authors have not declared a specific grant for this research from any funding agency in the public, commercial or not-for-profit sectors.

Competing interests None declared.

Patient consent Parental/guardian consent obtained.

Provenance and peer review Not commissioned; externally peer reviewed.

\section{REFERENCES}

1 Buchanan EP. In: Post TW, ed. Syndromes with craniofacial abnormalities. Waltham, MA: UpToDate Inc, 2018

2 Acke FR, Dhooge IJ, Malfait F, et al. Hearing impairment in stickler syndrome: a systematic review. Orphanet J Rare Dis 2012;7:84.

3 Snead MP, Yates JR. Clinical and molecular genetics of Stickler syndrome. J Med Genet 1999:36:353-9.

Copyright 2019 BMJ Publishing Group. All rights reserved. For permission to reuse any of this content visit https://www.bmj.com/company/products-services/rights-and-licensing/permissions/

BMJ Case Report Fellows may re-use this article for personal use and teaching without any further permission.

Become a Fellow of BMJ Case Reports today and you can:

- Submit as many cases as you like

- Enjoy fast sympathetic peer review and rapid publication of accepted articles

- Access all the published articles

- Re-use any of the published material for personal use and teaching without further permission

For information on Institutional Fellowships contact consortiasales@bmjgroup.com

Visit casereports.bmj.com for more articles like this and to become a Fellow 